Sabira STÅHLBERg (Helsinki) \& Ingvar SVANBeRg (Uppsala)

\title{
Gathering dog's tooth violet (Erythronium sibiricum) in Siberia
}

\begin{abstract}
Siberian dog's tooth violet (Erythronium sibiricum) was utilised as food by several ethnic groups in southern Siberia in the eighteenth century. It was an important vegetable supplement for groups that subsisted on hunting and fishing. E. sibiricum was gathered especially during the spring, but also rodent burrows were plundered by humans during the colder seasons. The plant was used as medicine and it was of local commercial importance. This ethnobiological article analyses the gathering, processing, conservation, preparation, consumption and nutritional significance of E. sibiricum on the basis of historical data. Questions of ethnographic, linguistic and other contacts between groups that can be identified from the use of this plant are raised, and, for comparative purposes, the use of other Erythronium species in Japan and North America is discussed.
\end{abstract}

\section{Introduction}

The roots of the Siberian dog's tooth violet, Erythronium sibiricum (Fischer et C. A. Meyer) Krylov (earlier known as Erythronium dens-canis var. sibiricum) were previously gathered for food by several peoples in southern Siberia. In addition to fishing and hunting, e.g. Barabin Tatars used to dig up dog's tooth corms (swollen underground plant stems) among other roots and bulbs from the steppe. They also plundered rodent burrows in order to fill their vegetable stores for the winter (Falck 1786: III: 539; Ståhlberg \& Svanberg 2010). Although the small, white, tooth-like corms from this modest plant were not as popular as the larger sarana bulbs in Russia and Siberia, the collection of these two plants cannot be separated. Most Erythronium roots were gathered together with sarana, which are usually identified as bulbs of different Lilium species. The gathering of dog's tooth is also closely connected with gathering lilyleaf ladybell (Adenophora lilifolia) as well as other edible plants (cf. Ståhlberg \& Svanberg 2006).

Erythronium sibiricum is a small herbaceous flowering plant of the Liliaceae or lily family. It is considered native to southern Siberia (Altai, Western Sayan), eastern Kazakhstan, northern Xinjiang (China) and Mongolia. It can be found in forests, thickets and subalpine grasslands. Related taxa are found in southern Europe (Erythronium dens-canis L.), the Caucasus and northern Iran (Erythronium caucasicum Woronow). A fourth Eurasian species, Erythronium japonicum Decaisne, is native to Japan, Korea, southern Kurile Islands and northeastern China (Mathew 1992). In Siberia Erythronium sibiricum has been observed and described under the generic name Erythronium dens-canis by travellers and researchers for about three centuries. This study discusses the period around 1770, when dog's tooth was still actively gathered for food. Dog's tooth was found mainly in the steppe, from the Tom and Irtysh 


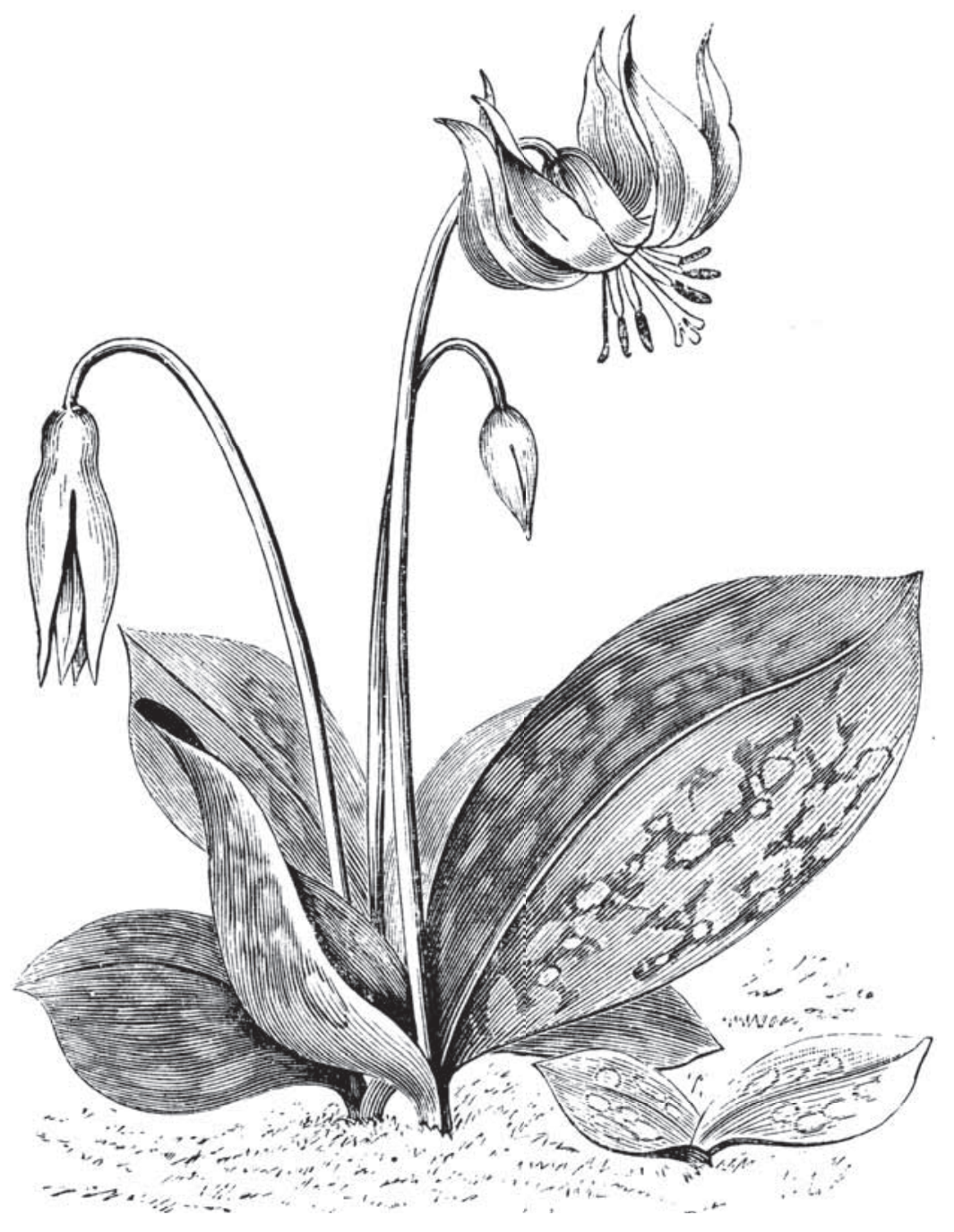

Figure I. Dog's tooth violet (Nicholson I884: 533).

rivers in the west to the $\mathrm{Ob}$ and Yenisei in the east, in the Kolyvan Mountains, the Baraba steppe and around Krasnoyarsk (Georgi 1800: 901; Falck 1786: II: 158). The gatherers of dog's tooth were, as far as we have been able to identify, predominantly Turkic nomadic or semi-nomadic peoples. However, also non-indigenous settled peoples, who lived in the vicinity of the gatherers, for example Russians, collected and used the corms.

The purpose of this article is to examine the process and methods of gathering, preparation and conservation of dog's tooth in Siberia from a historical perspective. We discuss the known uses of the plant and the techniques and traditions connected with it and try to identify the importance of dog's tooth corms for the local peoples 
(cf. Turner 1988) on the basis of eighteenth-century sources. Comparative perspectives from East Asia and North America are also provided. Using the plant as an example, we raise questions in such diverse fields as history, ethnology, linguistics and cultural contacts between different peoples in southern Siberia. On a regional level, this kind of ethnobiological knowledge contributes to several other fields of study, while at a global level our article adds to the growing amount of data about gathering and local use of the environment. This study is a complement to our previous article about sarana (Ståhlberg \& Svanberg 2006). The use of dog's tooth and its underground corms in Siberia has been mentioned only briefly in scientific literature until now (see Eidlitz 1969: 49).

\section{Sources}

Unlike researchers who work with contemporary gatherers, as historical ethnobiologists we cannot make field observations or interviews. The tradition of gathering dog's tooth has disappeared, but we can collect data from historical sources, travel narratives, linguistic materials (especially phytonyms), ethnological and botanical information and local technologies, e.g. for gathering and preparing the roots (see Balée \& Brown 1996; Svanberg 2007).

In the case of dog's tooth, our main and often only sources are travel reports written by explorers of the Russian Imperial Academy at the end of the eighteenth century. These explorers were sent from St. Petersburg to different areas of the expanding Russian Empire and lived for several years with local peoples. Most explorers, for instance Peter Simon Pallas and Johann Gottlieb Georgi, were Germans but there were a few Russians who travelled outside the present area, and Johan Peter Falck was Swedish (Ståhlberg \& Svanberg 2011). Their travel narratives were published within two decades after their journeys around 1770. Modern researchers are confronted by a number of challenges when using these sources. Lack of local knowledge and little understanding of gathering is the most apparent problem with the explorers; today we possess much more knowledge due to comparative research. Another easily identifiable topic is the abundance of biased attitudes - gatherers and hunters were generally seen as primitive beings. A comparative analysis between modern values and different European attitudes around 1770, including Linnaean and other scientific views, uncovers several similarities, but also some differences which will be taken into account in this study.

Source criticism applied to the travel narratives shows that a very important factor influencing the character and depth of data was the season(s), in which the explorers visited the gathering peoples. If the explorers were able to attest to the gathering process, their information is detailed, and if they could taste the cooked roots, the accounts are clearer than when only based on hearsay. Individual knowledge and other characteristics about the informants should be considered, but mostly we receive no clues as to who provided the information. Language difficulties - few of the explorers 
spoke local languages and they had to rely on interpreters - and the time and occasion when information was gathered, the relationships of the informants and groups among themselves and with the explorers are also important, but these are generally unknown. We can only make educated guesses about most of these factors, as the explorers only incidentally inform the reader about when, how and where an observation or interview took place.

The Academy explorers observed Siberian peoples gathering the roots of the dog's tooth at a time when the tradition was still part of the local economy. At the end of the eighteenth century, gathering was widely practised. Yet despite a general popularity of collecting wild plants among Siberian peoples, observations are scarce and scattered. There is even less information in later accounts, possibly due to a decline in the practice and disappearance of knowledge about the environment and the use of plants. Such knowledge is often today called local ecological knowledge, but we argue that it comprises much more than ecology. In our view, based on historical studies especially in Russia and Siberia, knowledge about the biota and the environment can be defined as a dynamic, non-written complex, consisting of information of all kinds, including observations, experiences, analysis, beliefs, traditions, techniques and technology (Cotton 1996: 60-61).

A complete identification of the local peoples in Siberia mentioned here with modern groups cannot be done for the above-mentioned reasons, in addition to historical aspects. Therefore we keep the eighteenth-century names and add modern clarifications in brackets when possible. Tatar in general means a Turkic people if not otherwise explained (see Ståhlberg \& Svanberg 2011).

\section{The plant and its names}

Siberian dog's tooth violet is one of at least 27 different Erythronium species in the world. It reaches a height of about 16 to $20 \mathrm{~cm}$. Erythronium species in general are beautiful plants that can spread through seeds or be grown from bulbs, which is often done today in gardens in Europe and North America where it is a popular ornamental plant. The white, oblong, tooth-like corms, up to ten centimetres long, have given the dog's tooth violet its European names which mostly contain the idea of a dog tooth. The corms are juicy when fresh, but dry up slowly after the flower has bloomed in spring (in Siberia between April and June, depending on region). The flower holds five petals which are up to five centimetres long, mostly pink, lilac or purple, but often also yellow or white.

The various Erythronium species prefer temperate zones in Eurasia and America, but being cold-resistant, they grow even in high mountains such as the Carpathians, the Pirin (Bulgaria), the Alps and several Siberian mountain areas, including the Altai. In Russia four species are identified so far: E. caucasicum, E. dens-canis, E. japonicum and E. sibiricum. E. dens-canis has for several decades been a protected plant in Europe and Russia because of its endangered status. In Romania, it used to be 
a popular ornamental flower and consequently the demands of the market have almost caused its extinction (Marossy 2006: 65-67). Although modern botanists warn users about Erythronium corms, because they can cause dermatitis to sensitive skin, no such problem is recorded in Siberia in historical times. The lack of information does not mean that the problem did not exist, however (cf. Gilyarov et al. 1989: 244a; Winter 1897: 331-333; Gmelin 1747: 39).

Folk names for plants are an important source for historical ethnobiology and research on migration, cultural, social, economic and linguistic contact (Svanberg 2007). Plant names can indicate the geographical extent of the plant's use, trade and other relations, how groups borrowed techniques and knowledge from each other and also measure to some degree the importance of the plant for the users. Here we only discuss certain aspects of the phytonyms; a linguistic analysis, etymologies, etc. would require a separate discussion.

For E. sibiricum, there are two main lines in Siberian linguistic materials: bis/ bes and kandyk. The first is found among the Turkic peoples Teleut, Sagai and Beltir, and also among the Tatars around Krasnoyarsk, who called the plant and the roots bess or bis 'dog's tooth'. The Sagai and Beltir are now considered sub-groups of the Khakas. The great importance these peoples attributed to the root was reflected in their calendars. It is customary for many peoples to name months after the plants that were gathered at a certain point in time or after main occupations during the season. In the Teleut time counting system, the third month, which would largely mean June (the first month was mostly April), was called bis ay 'dog's tooth month'. The roots of bis were dug up at this time. According to the explorer Peter Simon Pallas, however, the Sagai and Beltir women, who were the main gatherers, dug up the roots already in May. This earlier month was therefore called bess ay among the Sagai and Beltir (Pallas 1776: 349; Georgi 1776: 241; Gmelin 1747: 41). The Turkic peoples in the Altai Mountains also had an 'edible-lily bulb month' (Harrison 2007: 69-72).

A more widespread Turkic name for dog's tooth was kandik or kandyk, which was adopted by immigrant Russians (кандик, кандык). In modern Russian, kandyk means Erythronium species in general. The explorer Johann Gottlieb Georgi (1780: 487 ) informs us that where Russians lived close to Tatars, they gathered wild roots like their neighbours, especially kandyk and sarana. The word kandyk has been recorded among several groups, such as the Altai, Kachin, Kuznetsk and Tomsk Tatars, as well as among Russians in Siberia. Also the Turkic peoples Oirot and Koibal used the word kandyk. The Teleut and Sagai knew and used the word xandix in addition to bis. Several of these peoples called the first spring month, which among them meant March, kandyk ay. However, in Sagai the meaning of xandïx ay ï was June (Gmelin 1747: 41; Pallas 1776: 349; Falck 1786: II: 158; Georgi 1800: 901; Radloff 1899: 123; Baskakov \& Inkižekova-Grekul 1953: 484-485; Vasmer 1955: I: 518; Räsänen 1969: 231). There are also variations such as kadyk and kendyk (Vasmer 1955: II: 251; Gilyarov et al. 1989: 244a; Hauenschield 1989: 73).

Interestingly, a word similar to kandyk is found in Soyot. Xandyk-ara denotes a species of Sambucus, which is certainly not a dog's tooth. Both words have by 
researchers been referred to the word kanchyk 'bitch', but the etymology is not reliable and supposedly has been influenced by European names for Erythronium denscanis. This word, kanchyk, exists in several Turkic languages in various forms, for instance Tobolsk Tatar kancyk, Azeri kancıx and Bashkir kandyk, all meaning 'female dog'. A dog appears also in modern Turkish dialects, where the dog's tooth (E. denscanis) is called both alp lâlesi, literally 'alpine tulip' and köpekdişi, lit. 'dog's tooth' (Räsänen 1969: 230-231; Hauenschield 1989: 73).

The latter contains the same idea of a dog tooth as in European languages or is a direct translation of the plant's Latin name, Erythronium dens-canis. In some languages in Europe, the official name in translation exists parallel with folk names, which often have no connection to dogs (cf. Hungarian folk names from Romania; Borza 1968: 66). The Latin name was popularised by Linnaeus in 1753, who borrowed it from earlier sources. In European literature the name dens-canis 'dog's tooth' existed already from at least the 16th century (Linnaeus 1753: 305; Lange 1959: 561; Genaust 1996: 203).

\section{Gathering dog's tooth}

The corms of E. sibiricum should be gathered for food when the flower is in bloom in spring and early summer. Otherwise they start drying up and become, if not completely inedible, at least difficult to cook and they lose their taste (Winter 1897: 334). For gathering and preparation of the corms, detailed knowledge and specific technology were required in Siberia. It was important to recognise the right plant, check the roots and assess their quality. Our explorers unfortunately mention nothing about how this knowledge was collected, transferred and developed.

Vegetables of high quality were essential for the survival of the peoples in southern Siberia during winter. Although the Tatars around the Tom River and the town of Tomsk eagerly went out in the spring to dig up dog's tooth, they took care to examine the corms which they would eventually dry for their winter stores (Gmelin 1747: 39-40). Rotten or otherwise damaged corms did not keep through the cold season and could destroy other roots and bulbs in the stores as well. This would inevitably lead to a serious lack of vegetables in the diet until the next growing season.

Dog's tooth was often gathered together with other vegetables and conserved like them. Wilhelm Radloff (1884: I: 355) relates that the Shor gathered dog's tooth corms with martagon lily bulbs (Lilium martagon) and other edible roots such as anomalous peony (Paeonia anomala) and ramson (Allium ursinum). The roots were dried outside in the sun and then used immediately or stored for the winter. Many Siberian peoples gathered vegetables also from rodent burrows. This required knowledge about the surrounding environment and regular observation of animals and plants. An especially popular food "provider" throughout the year was the root vole, Microtus oeconomus. This vole gathers large amounts of high-quality vegetables in its underground stores. The caches could be plundered at any time of the year for fresh products (Ståhlberg \& Svanberg 2010). 
Technology was as important as knowledge and without the right instruments, reaching the dog's tooth roots could be very difficult. For the purpose of digging out rodent holes or corms from plants in the field, Siberian peoples developed special instruments. According to Pallas (1776: 349), the roots lie very deep in the soil and were often found under sturdy grass. Therefore Siberian peoples used a hoe which had a thin iron piece, "like a small Russian plough", fixed at one end. The wooden part of the hoe was slightly curved so that the digger easily could lift up the heavy soil. The spade had a small piece of wood fixed transversally and the digger could push the iron with his foot into the earth. The instrument was neither heavy nor big and most importantly, women could easily use it. There was in the view of Pallas no better or more comfortable instrument for digging up roots. Several peoples the explorers generally identified as "Tatars" called it ossuk. In Oirot, ozup was a small round spade which was used especially for dog's tooth. In Teleut, Shor, Sagai and Altai it was called ozyp, in Sagai and Khakas also uzyp and in Soyot ozuk (Räsänen 1969: 367; Radloff 1893: 1147). Similar spades are known also among the Bashkir in the Ural area (Gunda 1949: 377).

\section{Preparing and consuming Siberian dog's tooth violet}

When they had dug out the roots, the gatherers started to clean and sort their findings. If taken from rodent nests, the roots were already carefully cleaned by the animals. Then the gatherers and their families would consume the roots immediately, either raw or after cooking. Some also dried and then consumed the roots, alternatively dried and stored them for the winter, but most Siberian peoples consumed at least part of the harvest like fresh vegetables, immediately after digging it up from the earth. To conserve and prepare the roots properly, knowledge, techniques, recipes and skilled cooks were needed. The European explorers explain several uses and do not hesitate to suggest some dishes themselves.

According to an early traveller in Siberia, Johann Georg Gmelin (1747: 39-40), the Tatars around Krasnoyarsk and Tomsk were so greedy for the roots that there would be no plants or stores left in the autumn. If anything was to be stored for the winter, the Tatars would grind the dry roots and mix them with milk or cook them with meat soup into porridge. They also used the roots as other peoples cooked or roasted chestnuts. According to Gmelin, dog's tooth could easily and without any loss of taste replace chestnuts when filling roasted geese. It is interesting to note that there was another widely used plant which was gathered in the same areas as dog's tooth and used in a similar way. Ramson (Allium ursinum) was especially popular among the Altai, Tofalar, Karagas and local Russians (Potapov 1953: 70; Katanov 1891: 152; Eidlitz 1969: 48).

Sometimes dog's tooth would be cooked and served with meat, more or less like Europeans prepare potatoes today. In the nineteenth century, potatoes began to supplant the use of wild roots in northern Russia and Siberia. Dog's tooth corms could also be cooked in water and then put out to dry or, if eaten at once, cooked and mashed 
with milk or meat broth. Then, according to Georgi (1800: 901), they were so delicious that they qualified even "for better tables". Discussing taste, Gmelin (1747: 39-40) thought the roots were optimally nutritious. After being repeatedly cooked in milk, they were very pleasant to eat. The Sagai, for example, cooked the roots very slowly until soft and ate them with milk or cream. To Pallas' palate, however, the corms tasted like raw dough of wheat flour, water and eggs, and were "quite indigestible" (Pallas 1776: 349-350; Falck 1786: II: 158).

Like sarana bulbs, dog's tooth corms were often ground into flour after they had been boiled and dried in the sun. Sarana roots were used for baking bread, but there is no indication that E. sibiricum was used in a similar way (cf. Potapov 1953: 62). Dog's tooth corms are edible, but not very nutritious. The main reason for their use is probably the large amount of starch they contain, which makes them comparable to potatoes. As far as we know, only the roots were gathered in Siberia, not the parts of the plant above ground. However, the leaves are also edible raw or cooked as a vegetable or in a salad.

The corms of the dog's tooth can be eaten raw, cooked or dried as the examples above show. The starchy content of the corms provides good flour for noodles and cakes, which are nowadays sometimes produced by amateur gardeners in Europe and North America. In Siberia, dog's tooth flour was mostly used for porridge. In addition to starch, the corms contain sugars, gum and dextrose, all of which are found in large amounts when the flower blooms, but diminish as the bulb dries up towards autumn (Winter 1897: 333). Interestingly, Ainu women in northern Japan used to corms of Erythronium japonicum in late autumn. They cleaned, cooked and mashed them into a pulp and then made cakes, which were dried and eaten during the winter, providing extra starch to the diet (Bachelor 1892: 40). As already mentioned, in Siberia the gathering from the fields took place in spring.

\section{Subsistence, supplement, medicine and trade}

Winter stores were perhaps the most important reason for gathering roots of any edible kind among all peoples in southern Siberia. Without abundant stores they would suffer from hunger and probably some of the people would not survive until spring. Only a few groups subsisted on dog's tooth throughout the year. The Uriankhai along the Yenisei consumed dog's tooth corms during the cold season and also fresh in the warm period. "In summer reindeer milk is the staple diet", wrote an early twentiethcentury visitor (Carruthers 1913: 220), "supplemented by the roots of an herb called kandic - a liliaceous plant which they dig up with hoes in the forests. In winter they live on the powdered roots of this herb and on the salted meat of the game they killed in the previous autumn". Other groups subsisted on dog's tooth only in winter. The Tatars who lived close to the town of Tomsk and along the lower Tom River survived the cold season by consuming sarana (here Lilium martagon) and dog's tooth, which was extremely common in the area (Falck 1786: III: 492). 
To most Siberian peoples, however, dog's tooth violet was a vegetable supplement like other roots and bulbs and it was eaten occasionally with their ordinary fish- or meat-based diet. One example is the Baraba Tatars who consumed, according to Georgi (1776: 194), "everything that Muslims are allowed, but also pagan foods they used to eat before converting to Islam". These dietary customs which the fairly recently converted Barabin Tatars still kept included wild birds, fish, wild roots and bulbs such as lilies and onions (especially sarana, here Lilium martagon), Siberian dog's tooth violet, lady bell (Adenophora liliifolia), common sorrel (Rumex acetosa), Siberian angelica (Angelica dahurica) and common hogweed (Heracleum sphondylium), as well as berries, wild plants and leaves. Fish was consumed regularly in soups or dried and dog's tooth was often cooked with fish dishes.

In many cases we do not know if dog's tooth was included in the diet, because it is not explicitly mentioned. The Ostyak groups (probably Khanty, perhaps Selkup) whom Johan Peter Falck (1786: III: 464-465) visited, subsisted on ordinary fish soup, cooked or fried fish, caviar (tyrim) and a meal made from crushed small, air-dried fish called pors. The crushed fish was eaten sometimes like bread and sometimes cooked. All kinds of meat, grain traded from fur exchange with Russians, eggs, wild roots and bulbs from Lilium martagon, called tagul (cf. sarana), and "many wild fruits" were included in the diet. There is a possibility that dog's tooth was included in the assortment of wild plants together with other roots, but as no source confirms this we cannot be certain. There is of course a possibility that Uralic groups, in the same way as Russians living near Turkic peoples who gathered the plant, collected the same plants.

The Siberian Tatars used dog's tooth not only for food, but they also made an alcoholic drink from the roots. The corms were further used for medicine, especially against tapeworm and colic, another stomach ailment. The roots are reported to have had applications even for epilepsy and as an aphrodisiac (Dragendorff 1878: 7; Gilyarov et al. 1989: 244a). Gmelin (1747: 39-40), who first reported these medicinal and other usages, doubted the healing effect of Erythronium. He noticed that eating it in large quantities did not improve the health of the Tatars and it had little effect on the tapeworm which frequently troubled them. Erythronium japonicum violet has been used for medicinal purposes in Korea (Johnson 1998: 329).

Dog's tooth was a very popular food item in some areas and an object of trade. The Tatars along the Yenisei and in the Kuznetsk mountain area, who were very poor and lived in small, scattered settlements, were especially fond of the plant. Their main occupation was hunting, but they were also active in gathering vegetables for the winter, mainly Erythronium sibiricum. Unfortunately it grew only to a very small size and very sparsely around Abakan. The biggest and most beautiful roots, according to Pallas (1776: 349), were dug up at Mrasa and Kondoma by the local Tatars, who sold the vegetables as far as Abakan. Even fine town dwellers bought the roots because of their delicious taste, and the Tatars could return home with a handsome profit (Falck 1786: II: 158). 


\section{Comparative perspectives}

In Siberia, Erythronium sibiricum was used mainly for food and only to a limited extent as medicine or for other purposes. We have no information on the use of the other Erythronium species in western Eurasia. E. japonicum was gathered, however, in Hokkaido by the Ainu and eaten. It is called katakuri (cf. Japanese katakuriko 'starch', from kuri 'chestnut'). Nowadays starch with the same name is processed from potatoes which is much cheaper (Hosking 1997: 218).

In order to understand the extent and importance of Siberian dog's tooth gathering it is useful to look to the other side of the Pacific Ocean. In North America, several indigenous groups used Erythronium for food and medicine just like the Siberian peoples (Coffey 1993: 303-305). Many more Erythronium species grow on that continent than in Eurasia. American Indians knew and gathered many of them and often possessed more advanced techniques for gathering and processing than the peoples in Siberia, but there are some striking similarities. Like among Siberian peoples, dog's tooth was dried by Okanagan-Colville and Shuswap Indians for the winter. Winnebago Indians ate the raw plants, digging for them when they were fresh in spring and children were especially fond of the corms (Gilmore 1919: 71; Palmer 1975: 54; Turner et al. 1980: 45).

In contrast to Siberia, many Erythronium species were used for food and medicine in the Americas and often the whole plant was utilised. The Thompson Indians used E. mesochoreum and yellow dog's tooth (E. grandiflorum) for food, considering the last a very important and valuable nutritional source (Turner 1988, Turner et al. 1990: 123-124). Corms of E. oregonum were dug up and dried among the Kwakiutl, and E. revolutum was eaten by the Southern Kwakiutl. The latter dried the roots in the sun and boiled them. They then mixed the roots with grease and served them during large celebrations. The roots were considered a delicacy of great value (Turner \& Bell 1973a: 75; 1973b: 272). E. americanum was used among the Cherokee for medicine. They warmed the leaves, crushed them and poured the juice over wounds that would not heal. The Iroquois used the raw plant as a contraceptive, taking everything except the roots. The Montana Indians used E. grandiflorum, applying the crushed roots to boils (Moerman 1998: 227).

These short examples show that there was much more variation in the American usages of Erythronium plants than in Siberia. Furthermore, Siberian folk plant names, methods of gathering and preparation and tools are very similar to each other, unlike the more diversified American Indian traditions. The comparison leads to the conclusion that probably at least some if not several Siberian peoples borrowed techniques and knowledge from each other. How, when, who, where and why are the main questions of a complex discussion, which requires a broad geographical, linguistic and ethnological study. The only contact-induced practice we can clearly identify from the sources is that of the previously mentioned immigrant Russians learning to collect dog's tooth corms from their Turkic neighbours. Another important question is if Siberian and American customs are related, have originated from the same source, have appeared as the result of exchange or have developed separately. Similar 
questions need to be asked about all practices that are common to Siberia and North America, such as sarana gathering, the practice of plundering rodent burrows for vegetables, etc.

We do not know for how long dog's tooth has been used in the Northern Hemisphere and if the use of the corms is a remnant of ancient gathering practices. How the tradition came into being and how it has developed are questions that involve important topics such as population migration patterns and linguistic, economic and cultural contacts, especially between close neighbours in southern Siberia, and also between more distant Siberians and North American peoples. How do plant gathering techniques and names reflect contacts and exchange? From the examples of sarana and the plundering of rodent stores for vegetables, we know that there is a close link between Siberia and North America (Ståhlberg \& Svanberg 2006, 2010). What exactly this link might be and how it originated and developed over the centuries are important matters for further study. There is not yet enough research to answer these questions. The comparative study of plant, animal and other natural resources, their uses and traditions could provide a useful key to at least some answers.

\section{Conclusion}

Various wild plants have been used among different peoples in Siberia for centuries as delicacies, food, spices, emergency food supplies and medicine. Some of these plants possess certain nutritional or medicinal qualities while others contain mainly starch, like dog's tooth. Except when eaten as main dishes, porridge or snacks, dog's tooth corms were often used on the side with meat and fish, just like potatoes are cooked and served today as a supplementary dish (cf. Eidlitz 1969: 41).

The practice of gathering and consuming Erythronium sibiricum was not as geographically widespread as sarana, which was common among several peoples from the Volga region to Kamchatka. Dog's tooth gathering was limited to the growth area of the plant, in southern Siberia between the Irtysh and Yenisei Rivers. Sarana and dog's tooth were mostly gathered together in this region. The distribution of the names for dog's tooth in local languages, bess/bis and kandyk/kandik, reflects close contacts between some of the groups or points to a common origin. The latter folk name has been in vast use, probably because the word was taken up by Russians in Siberia together with the practice of gathering the roots. The Russians spread the term further and it is possible that at least some of the groups picked up the name from them. A diachronic linguistic analysis is required to solve this question (cf. Ståhlberg \& Svanberg 2006: 154).

The historical importance of gathering, preparing and conserving dog's tooth corms can be defined as average for most Siberian peoples. The most typical consumers were the Barabin Tatars, who gathered the roots for side dishes and as supplementary food, but did not subsist on them. For a few others, such as the Tomsk Tatars, the corms played a more important role, and the Yenisei and Kuznetsk Tatars even drew financial profit from gathering and selling the roots in town markets. For 
a few peoples such as the Uriankhai, the roots formed a crucial source of food during the winter. However, dog's tooth never played a merely marginal role in Siberia, such as e.g. a spice or a rare delicacy. On the contrary, it was abundant and several groups subsisted periodically and partly or completely on dog's tooth, often throughout the cold seasons, which could mean up to half of the year.

E. sibiricum was mainly a seasonal product in Siberian households. Although many peoples gathered the root from rodent stores in autumn and winter, spring remained the most important season and the corms were often consumed immediately. Whole families would dig up roots together, even though women were the main gatherers. A century ago, Waldemar Bogoras (1904: 199) observed that vegetable food in Siberia was much more used by women and children than by men. This is an important social aspect which requires more study. Also, comparative examples from North America show that Siberian traditions concerning Erythronium did not widely vary. The reasons for this and the contacts between Siberia and North America need to be researched further.

Gathering vegetables from the environment as an economic and dietary practice gradually diminished in Siberia during the nineteenth century. Political and economic changes, increasing immigration by Russians and the establishment of new, predominantly agricultural settlements were the main causes. Around the beginning of the twentieth century, only limited gathering of natural resources still prevailed in Russia and Siberia. The extent can be compared with Finland, the Baltic countries, Scandinavia and Eastern Europe. Gathering was often used only as a supplement to the diet or for emergency food supplies (cf. Manninen 1931: 30-31).

The study of the previous diet, human subsistence on wild plants, the use of plants and gathering techniques is important for our understanding of the historical situation, ecology, climate, resources, cultures, languages, economy, politics and changes in a certain region (cf. Lévi-Strauss 1962: 7-15). The gathering and preparation of dog's tooth corms in Siberia reflect a lifestyle based on local resources, a close relationship with nature and a profound knowledge of the environment. Dog's tooth use illuminates several aspects of the complex relationship between humans and nature and also between humans of different ethnic, cultural and linguistic background.

\section{References}

Balée, William \& Brown, J. C. 1996: Ethnobotany. - David Levinson \& Melvin Ember (eds), Encyclopedia of Cultural Anthropology. Vol. 2. New York: Henry Holt. 399-404.

Bachelor, John 1892: The Ainu of Japan. Vol. 1. London: Religious Tract Society.

Baskakov \& Inkižekova-Grekul = Баскаков, Николай Александрович \& ИнкижековаГрекул, А. И. 1953: Хакасско-русский словарь. Москва: Гос. изд-во иностранных и национальных словарей.

Bogoras, Waldemar 1904: The Chukchee. Vol. 1. Leiden: E. J. Brill.

Borza, Aleksandru 1968: Dicţionar etnobotanic cumprizînd denumirile populare româneşti şi în alte limbi ale plantelor din România. București: Academiei Republicii Socialiste România. 
Carruthers, David 1913: Unknown Mongolia: a Record of Travel and Exploration in NorthWest Mongolia and Dzungaria. London: Hutchinson.

Coffey, Timothy 1993: The History and Folklore of North American Wildflowers. Boston: Houghton Mifflin.

Cotton, C. M. 1996: Ethnobotany: Principles and Applications. Chichester: John Wiley.

Dragendorff, Georg 1878. Analyse der Zwiebeln von Erythronium dens canis L. - Archiv der Pharmacie, 3. Reihe, 57: 7-13.

Eidlitz, Kerstin 1969: Food and Emergency Food in the Circumpolar Areas. Studia Etnographica Upsaliensia 32. Uppsala: Almqvist \& Wiksell.

Falck $=$ Falk, J. P. [Johan Peter] 1786: Beyträge zur topographischen Kenntnis des Russischen Reichs. Vol. II \& III. St. Petersburg: Kayserl. Academie der Wissenschaften.

Genaust, Helmut 1996: Etymologisches Wörterbuch der botanischen Pflanzennamen. Basel: Birkhäuser.

Georgi, J. G. [Johann Gottlieb] 1775: Bemerkungen einer Reise im Russischen Reich im Jahre 1772. St. Petersburg: Carl Willhelm Müller.

Georgi, J. G. 1776: Beschreibung aller Nationen des Russischen Reichs. Vol. II. St. Petersburg: Carl Willhelm Müller.

Georgi, J. G. 1780: Beschreibung aller Nationen des Russischen Reichs. Vol. IV. St. Petersburg: Carl Willhelm Müller.

Georgi, J. G. 1800: Geographisch-physikalische und naturhistorische Beschreibung des Russischen Reichs. Königsberg: Friedrich Nicolovius.

Gilyarov = Гиляров, M. C. et al. (eds) 1989: Биологический энииклопедический словарь. Москва: Советская энциклопедия.

Gilmore, Melvin R. 1919: Uses of Plants by the Indians of the Missouri River Region. Bureau of American Ethnology Annual Report 33. Government Printing Office, Washington: Smithsonian Institution.

Gmelin, J. G. (Johann Georg) 1747: Flora Sibirica. Vol. I. Petropoli: Academiae Scientiarum.

Gunda, Béla 1949: Plant gathering in the economic life of Eurasia. - Southwestern Journal of Anthropology 5 (4): 369-378.

Harrison, K. David 2007: When Languages Die: The Extinction of the World's Languages and the Erosion of Human Knowledge. Oxford: Oxford University Press.

Hauenschield, Ingeborg 1989: Türksprachige Volksnamen für Kräuter und Stauden. Wiesbaden: Harrassowitz.

Hosking, Richard 1997: A Dictionary of Japanese Food. Singapore: Tuttle Publishing.

Johnson, Timothy 1998: Ethnobotany Desk Reference. Boca Raton: CRC Press.

Katanov = Катанов, Н. Ф. 1891: Поездка къ Карагасамъ въ 1890 году. С. Петербург: Паровая Скоропечатния Яблонского.

Lange, Johan 1959: Ordbog over Danmarks Plantenavne. Vol. 1. København: Ejnar Munksgaards Forlag.

Lévi-Strauss, Claude 1962: La pensée sauvage. Paris: Plon.

Linnaeus, Carl 1753: Species Plantarum. Vol. 1. Stockholm: Lars Salvius.

Manninen, Ilmari 1931: Überreste der Sammlerstufe und die Notnahrung aus dem Pflanzenreich bei den nordeurasischen, vorzugsweise den finnischen Völkern. - Eurasia septentrionalis antiqua VI: $31-48$.

Mathew, Brian 1992: A taxonomic and horticultural review of Erythronium L. (Liliaceae). Botanical Journal of the Linnean Society 109: 453-471. 
Marossy, Anna 2006: Wild plant species endangered through intensive harvest. - Dan Gafta \& John Akeroyd (eds), Nature Conservation: Concepts and Practice. Berlin: Springer. 65-67.

Moerman, Daniel E. 1998: Native American Ethnobotany. Portland: Timber Press.

Nicholson, George 1884: The Illustrated Dictionary of Gardening. Div. VI, Vol. 1. London: L. Upcott Gill.

Pallas, P. S. (Peter Simon) 1776: Reise durch verschiedene Provinzen des Russischen Reichs. St. Petersburg: Kayserl. Academie der Wissenschaften.

Palmer, Gary 1975: Shuswap Indian Ethnobotany. - Syesis 8: 29-51.

Potapov = Потапов, Л. П. 1953: Пища алтайцев (этнографический очерк). - Сборник Музея антропологии и этнографии Ак. Наук СССР 14: 37-71.

Radloff, Wilhelm 1884: Aus Sibirien. Leipzig: T.O. Weigel.

Radloff, Wilhelm 1893: Versuch eines Wörterbuch der Türk-Dialecte Vol. 1. St. Petersburg: Imperatorskoi Akademii Nauk.

Radloff, Wilhelm 1899: Versuch eines Wörterbuch der Türk-Dialecte Vol. 2. St. Petersburg: Imperatorskoi Akademii Nauk.

Räsänen, Martti 1969: Versuch eines etymologischen Wörterbuchs der Türksprachen. Helsinki: Suomalais-Ugrilainen Seura.

Ståhlberg, Sabira \& Svanberg, Ingvar 2006: Sarana in Eurasian folk botany. - Journal de la Société Finno-Ougrienne 91: 133-157.

Ståhlberg, Sabira \& Svanberg, Ingvar 2010: Gathering food from rodent nests in Siberia. Journal of Ethnobiology 30 (2): 184-202.

Ståhlberg, Sabira \& Svanberg, Ingvar 2011: Wild animals in Russian, Siberian and Central Asian households according to eighteenth-century travel reports. - Journal de la Société Finno-Ougrienne 93: 353-384.

Svanberg, Ingvar 2007: Plant knowledge as indicator of historical cultural contacts. - Andrea Pieroni \& Ina Vandebroek (eds), Travelling Cultures and Plants: The Ethnobiology and Ethnopharmacy of Human Migrations. Studies in Environmental Anthropology and Ethnobiology 7. New York: Berghahn Books. 226-244.

Turner, Nancy J. 1988: “The importance of a rose": Evaluating the cultural significance of plants in Thompson and Lillooet Interior Salish. - American Anthropologist, New Series 90: 272-290.

Turner, Nancy C. \& Bell, Marcus A. M. 1973a: The ethnobotany of the Coast Salish Indians of Vancouver Island 1. - Economy Botany 25: 63-99.

Turner, Nancy C. \& Bell, Marcus A. M. 1973b: The ethnobotany of the Southern Kwakiutl Indians of British Columbia. - Economy Botany 27: 257-310.

Turner, Nancy J. \& Bouchard, R., \& Kennedy, Dorothy I. D. 1980: Ethnobotany of the Okanagan-Colville Indians of British Columbia and Washington. Victoria: Royal British Columbia Provincial Museum.

Turner, Nancy J. \& Thompson, Laurence C. \& Thompson, M. Terry \& York, Annie Z. 1990: Thompson Ethnobotany. Knowledge and Usage of Plants by the Thompson Indians of British Columbia. Victoria: Royal British Columbia Provincial Museum.

Vasmer, Max 1955: Russisches etymologisches Wörterbuch. Heidelberg: Winter.

Winter, Paul A. 1897: Zur Naturgeschichte der Zwiebel von Erythronium dens canis L. Plant Systematics and Evolution 47: 331-335.

Sabira Ståhlberg <http://www.sabirien.net $>$

Ingvar Svanberg <ingvar.svanberg@ucrs.uu.se> 